\title{
THE EQUATORIAL GLACIERS OF EAST AFRICA
}

\author{
By Lieutenant-Commander P. C. SPINK, R.N.V.R. \\ METRIC.EQUIVALENTS OF HEIGHTS IN FEET

$\begin{array}{rlrl}3,000 \mathrm{ft} . & =914 \mathrm{~m} . & 13,000 \mathrm{ft} . & =3,962 \mathrm{~m} . \\ 9,000 \mathrm{ft} . & =2,743 \mathrm{~m} . & 15,000 \mathrm{ft} .=4,571 \mathrm{~m} . \\ 10,000 \mathrm{ft} . & =3,047 \mathrm{~m} . & 17,000 \mathrm{ft} .=5,181 \mathrm{~m} . \\ 1 \mathrm{I}, 000 \mathrm{ft} .=3,352 \mathrm{~m} . & 19,000 \mathrm{ft} .=5,791 \mathrm{~m} . \\ 12,000 \mathrm{ft} .=3,657 \mathrm{~m} . & 20,000 \mathrm{ft} .=6,095 \mathrm{~m} .\end{array}$

ALTHOUGH much has been written about the behaviour and fluctuations of glaciers in high latitudes during recent decades, little has been said about those near the equator. The recent war provided opportunities for investigating the glaciers of two important equatorial peaks in East AfricaKilimanjaro and Mount Kenya (see photographs, p. 28r). The following is a brief summary of the main observations which were made.

Kilimanjaro (í9,565 FT.) Lat. $3^{\circ}$ S., Long. $37^{\circ}$ E.

This peak, the highest in Africa, lies on the north-east frontier of Tanganyika. It consists of two high peaks joined by a long saddle at an elevation of $15,000-16,000 \mathrm{ft}$. One peak is the icecapped dormant volcanic crater of Kibo and the other, Mawenzi ( $17,560 \mathrm{ft}$.), is an extinct volcanic plug, virtually bare of permanent snow and ice and vulcanologically older than Kibo. These mountain masses together cover an area of over $40 \mathrm{sq}$. mi. above the $16,000 \mathrm{ft}$. contour.

The author visited the Kibo summit on three occasions between 1943 and 1945 . The object, in addition to mapping the true crater or "ash pit," was to ascertain the temperatures of the fumaroles and also to measure and demarcate by pegs the sulphur beds in the ash pit area. On the first visit it was immediately apparent to one familiar only with high latitude glaciers that the formations and weathering of the Kibo glaciers showed unusual features meriting further investigation.

Kibo consists of an area some 3 miles square above an altitude of $19,000 \mathrm{ft}$. It is rimmed with enormous and disjointed glaciers, the ice cliffs on the outside towering to heights of $300-400 \mathrm{ft}$. $(90-120 \mathrm{~m}$.), and on the inside to a maximum of $15 \circ \mathrm{ft}$. $(45 \mathrm{~m}$.). These glaciers are dead, since they are no longer fed from an inner and continuous source of ice as in ages past. The result is a slow but perceptible annual retreat. On the inside of these glaciers and some hundreds of feet below on a flat-lying area lies the caldera where large individual ice cliffs stand in various stages of disintegration. Between these, large areas of the lava floor are visible. These inner cliffs are remains of the once massive and possibly unbroken ice dome which formerly capped Kibo. On the northwest side of the caldera lies the true crater, an almost perfectly circular area about $400 \mathrm{yd}$. $(365 \mathrm{~m}$.) in diameter, with an inner cone some $400 \mathrm{ft}$. ( $120 \mathrm{~m}$.) deep partially surrounded with extensive sulphur beds and many active fumaroles. This area is relatively free of ice and snow, chiefly by virtue of fumarolic heat and insolation effects.

The north-east border of the ice cap reaches only slightly below the edge of the caldera (about $19,500 \mathrm{ft}$.), whereas on the south-west side it descends to the $15,000 \mathrm{ft}$. level. This oblique position of the ice cap from north-east to south-west is due to the fact that the western end is subjected to considerable diurnal cloud cover induced by the south-east monsoons. This causes greater precipitation on the windward side, at the same time partially protecting the western glaciers from the destructive effects of an equatorial sun.

The glaciers provide interesting material for the study of ice formation by the glaciologist, since the vertical rays of the equatorial sun cause some curious and almost freak ablation effects. 
A characteristic feature of the inner glaciers is the vertical weathering and fluted appearance of the ice walls. There are also individual ice pinnacles surrounded by the bare lava floor. These individual relics disappear relatively quickly, since they are subjected to considerable heat radiation from the surrounding lava. As a check upon the future rate of melting a circumferential measurement of one of the most conspicuous ice blocks in the caldera was made by the author in February 1945. Nieve penitente formations are common. The laminated effect is most noticeable in the comparatively flat caldera where the sun's rays strike vertically and with full force (incidentally causing a great diurnal temperature range), whereas on the outer slope of the glaciers the sun strikes at an oblique angle. Even so, on the glaciers of the outer slopes the present rate of erosion and ablation of the firn surfaces, particularly of the outer southern hanging glaciers, is very rapid.

It is obvious that the glaciers are in process of dissolution. Little new ice is being formed, since the annual snowfall is insufficient to balance the constant recession. Marked ablation of the smooth firn surfaces of the glaciers is apparent in many places. The surfaces have developed a corroded appearance, and formations of huge horizontal and parallel ice steps are common.

\section{MoUnt KenYa ( 77,040 FT.) Lat. $0^{\circ}$ S., Long. $377^{\circ} \mathrm{E}$.}

In contrast to Kilimanjaro, the single dead volcanic mass of Mount Kenya is alpine in appearance and consists of a rock mass culminating in two jagged twin peaks. Vulcanologically the mountain is far older than Kibo and is geologically contemporary with the Mawenzi peak of Kilimanjaro. In common with Mawenzi, this rock mass is the plug of a once considerably higher volcano.

Unlike the unique remnants of Kibo, the Mount Kenya glaciers generally are orthodox in type and behaviour. Due to the steep gradients and system of deep U-shaped valleys radiating from the summit mass, the glaciers consist mainly of hanging and valley types, all of which appear to be active but receding. Several showed signs of slow disintegration, and in some instances marked ablation of the firn surfaces was apparent. Since the Mount Kenya glaciers have a very steep gradient, a vertical sun strikes the surface at an oblique angle. This probably accounts for the fact that nieve penitente formations are comparatively rare.

An important feature common to both Kibo and Mount Kenya is the relative absence of seracs in the hanging and valley glaciers. This is a characteristic of equatorial glaciers and has been commented upon by Himalayan and Andean explorers. The reason is ascribed to the toughness of the ice, possibly caused by its subjection to a far greater temperature range than is normal in higher latitudes. This "plasticity" results in an ice sheet tending to bend rather than break over a fall.

A high rate of evaporation added to the effects of a great diurnal temperature range may contribute to the many ice pinnacles to be found on Kibo. The combined effect of strong evaporation and tropical insolation is a problem for physicists; it is significant that nieve penitente and pronounced ice pinnacles are associated with high altitudes in tropical zones. These are commonest on comparatively flat areas, such as the Kibo caldera, particularly where the ice sheets are melting irregularly, exposing the ground to insolation, which in turn radiates heat strongly against the vertical sides of individual relic ice masses.

At the time of the first climb in 1899 there were 15 separate glaciers on Mt. Kenya; even as late as 1926 a map showed 14. To-day there are but 10. The retreat of the glaciers has accelerated during the past few years and is synchronous with a rapid fall in the Rift Valley lake levels due to drier climatic conditions.

Ruwenzori (16,800 FT.) Lat. $0^{\circ}$ N., Long. $30^{\circ} \mathrm{E}$.

The Ruwenzori Range consists of a non-volcanic chain of peaks, orientated north-north-east for about 70 miles ( $112 \mathrm{~km}$.) and lying on the boundary of the Belgian Congo and Uganda. Mainly 
because of the consistently moist inland conditions of both the Congo and Uganda, this range experiences an annual rainfall of as much as $200 \mathrm{in} .(508 \mathrm{~cm}$.). As a result of the immense snowfall and cloud protection from equatorial insolation, the glaciers, which are very large and to some extent still unexplored, in many instances descend almost to the vegetation line. Consistently with the other glaciers of East Africa, they show every sign of recession. It should be emphasised, however, that thanks to high precipitation due to a favourable geographical position, the Ruwenzori glaciers are far "healthier," more vigorous and better nourished than the atrophied remnants on Kibo and Mount Kenya.

\section{The Climatological Aspect}

There is no better index of relatively recent climatic changes affecting a country than evidence of fluctuations in the former extent of glaciers on its high peaks correlated with corresponding rises and falls in the levels of lakes lying in the intermontane regions. There are sufficient high peaks in East Africa to supply this index. On Kilimanjaro, Mount Kenya and Ruwenzori there are the surviving remnants of once vast glacierized areas. In addition, rock striations, moraines and U-shaped valleys furnish proof that it is only very recently, geologically speaking, that the glaciers melted on Elgon and Sattima in Kenya. There are several similar cases among the high peaks of Abyssinia.

It is not within the scope of this article to deal with the interesting subject of past and present climatic changes in relation to glaciers of all latitudes. It is a well-known fact that throughout the world glaciers in all latitudes are showing marked signs of retreat. In many instances this phase has shown signs of acceleration during the past ten decades. Professor H. W. Ahlmann has recently drawn attention to the present phase of amelioration of climate in high latitudes accompanied by pronounced recession of glaciers in Scandinavia, Iceland, Greenland and elsewhere. In a lette written to the author last year, Ahlmann says, in reference to the shrinkage of equatorial African glaciers, that in his opinion this desiccation is another aspect of climatic fluctuation which, in higher northern latitudes, has taken the form of a climatic improvement.

It is interesting to note that there is plenty of evidence of Pleistocene glaciation in low latitudes. To mention a few examples, on Wilhelmina Peak (16,518 ft.), in the Orange Mountains of New Guinea, there is an old glacier lake with striated rocks lying at 13,500 ft. Former glaciations on Mount Carstensz ( $16,400 \mathrm{ft}$.) in New Guinea, have been traced as low as $12,000 \mathrm{ft}$. It has been established that Pleistocene glaciers covered Mauna Kea ( $13,784 \mathrm{ft}$.), in Hawaii, down to $11,700 \mathrm{ft}$. At Lake Titicaca, in the Andes, beaches have been found 350-400 ft. (107-120 m.) above the present lake, and much morainic evidence of longer glaciers has been established. In East Africa, Mount Elgon (14,178 ft.) and the Aberdare Mountains (13,000 ft.) and at least three peaks in Abyssinia which are not now glacierized indicate former glaciations. This is particularly the case on the old volcanic mass of Mount Elgon, where the evidence is very pronounced.

\section{Evidence of Former Extensions of the Glacirrs}

On all three mountain masses there is abundant evidence of the former great extension of the glaciers at the time of the Quaternary maximum. On Kilimanjaro, moraines can be seen on the saddle between Kibo and Mawenzi at 15,000 ft. and striated rocks are lying at 13,000 ft. The lowest extension of the ice to-day is about 15,000 ft. on the south-west side. South of Mawenzi, moraines can be seen at $\mathrm{rr}, 800 \mathrm{ft}$. Indeed, terminal moraines can be found at various heights suggesting minor oscillations of advance and retreat, but the general trend is retreat. It is a fair assumption that formerly there was an almost unbroken ice dome covering Kibo, and that the present-day glaciers are but dead and rapidly receding survivors of that great ice mass. Judging by former photographs and the author's acquaintance with the glaciers over a period of three 
years, the rate of retreat is startling. It has been assessed recently, for example, that the tongue of the Penck Glacier on the west-north-west side of Kibo has retreated $400-500 \mathrm{yd}$. $(365-460 \mathrm{~m}$.) since $x 934$ and is decaying rapidly. This is a spectacular rate of retreat which calls for confirmation. A more reliable estimate, perhaps, is a recent measurement of the recession of the Darwin glacier on the south-west side of Mount Kenya. This works out at $200 \mathrm{ft}$. $(6 \mathrm{I} \mathrm{m}$.) in the last twenty-five years.

On Mount Kenya, the lowest limit appears to have been about $9000 \mathrm{ft}$. compared with to-day's level of $14,000-14,500 \mathrm{ft}$. Large moss-covered terminal moraines are lying in the bamboo forest at $9800 \mathrm{ft}$. It is estimated that the Quaternary glaciers formerly covered roo sq. mi. $\left(259 \mathrm{~km} .{ }^{2}\right)$ and extended as low as $9000 \mathrm{ft}$. On the southern slopes are three enormous moraine ridges extending to the forest belt. Morainic ridges are common and usually lie several hundred feet from the snouts of existing glaciers. The former glaciers carved out a series of eight large radial $U$-shaped valleys which are a scenic feature of the mountain. Evidence of former large rivers fed by these valley glaciers is to be seen in the extensive alluvial deposits and water-borne boulders lying many feet above the present levels of the stream of to-day.

On Ruwenzori the former extensions were as low as $6600 \mathrm{ft}$. and terminal moraines are now lying buried in luxuriant forest. This is particularly the case in the Mobuku Valley, where the moraines are larger than those on any other peak in East Africa. These marked differences in former levels can be explained by the respective geographical positions of the three alpine zones. Kilimanjaro rises abruptly from hot and arid plains at the 3000-ft. level. Mount Kenya and Ruwenzori rise from a much higher hinterland with correspondingly higher bases.

Summing up, it is apparent that all the glaciers are receding on the three surviving glacierized peaks of East Africa. On the Kibo summit of Kilimanjaro and on Mount Kenya the retreat is fairly rapid. On Ruwenzori it is slower though still marked. Kibo now possesses large dead remnants. On Kenya the glaciers are alive but shrinking. It may be no exaggeration to suggest that, if the present desiccation in East Africa persists, the glaciers of Kibo and Mount Kenya, depending on precipitation from the Indian Ocean, will disappear entirely within one or two centuries through lack of nourishment. The higher rainfall of the Ruwenzori area, which, due to its geographical position, is derived from both the Atlantic and Indian Oceans, should ensure the preservation of its glaciers for several centuries to come.

Present-day photographs of individual ice masses in the Kibo caldera, compared with those taken in the early years of the century, reveal remarkable changes and emphasize the rapid rate of decay and retreat. A series of biannual photographs taken from-fixed points would be of great comparative value. It is also suggested that photographic aerial surveys of these surviving glacierized peaks be taken at intervals as a check upon their rates of retreat.

MS. received 22, December 1947

\section{RE F E R E N C E S}

Geilinger, W. The Retreat of the Kilimanjaro Glaciers. Tanganyika Notes and Records (Dar-es-Salaam), Vol. 2, r936, p. 7-21.

Nilsson, E. Quarternary Glaciation and PIuvial Lakes in B. E. Africa. Geografiska Annaler, Vol. 13, 1931, p. $249-349$. Nilsson, E. Ancient Changes of Climate in B. E. Africa and Abyssinia. Geografiska Annaler, Vol. 22, I940, p. 1-79.

Spink, P. C. Some Effects of Vertical Insolation upon the Kilimanjaro Glaciers. Quart. Fourn. Roy. Met. Soc., Vol. 69, r 943 , p. $26 \mathrm{I}-64$.

Spink, P. C. Weather and Volcanic Activity on Kilimanjaro. Geog. Fourn., Vol. 103, 1944, p. $226-29$.

Spink, P. C. Further Notes on the Kibo Inner Crater and Glaciers of Kilimanjaro and Mount Kenya. Geog. Fourn., Vol. 106, 1945, p. $210-16$.

Spink, P. C. World-wide Climate and the Glaciers and Lake Levels of East Africa. Weather, Vol. 2, 1947, p. 329-37. 


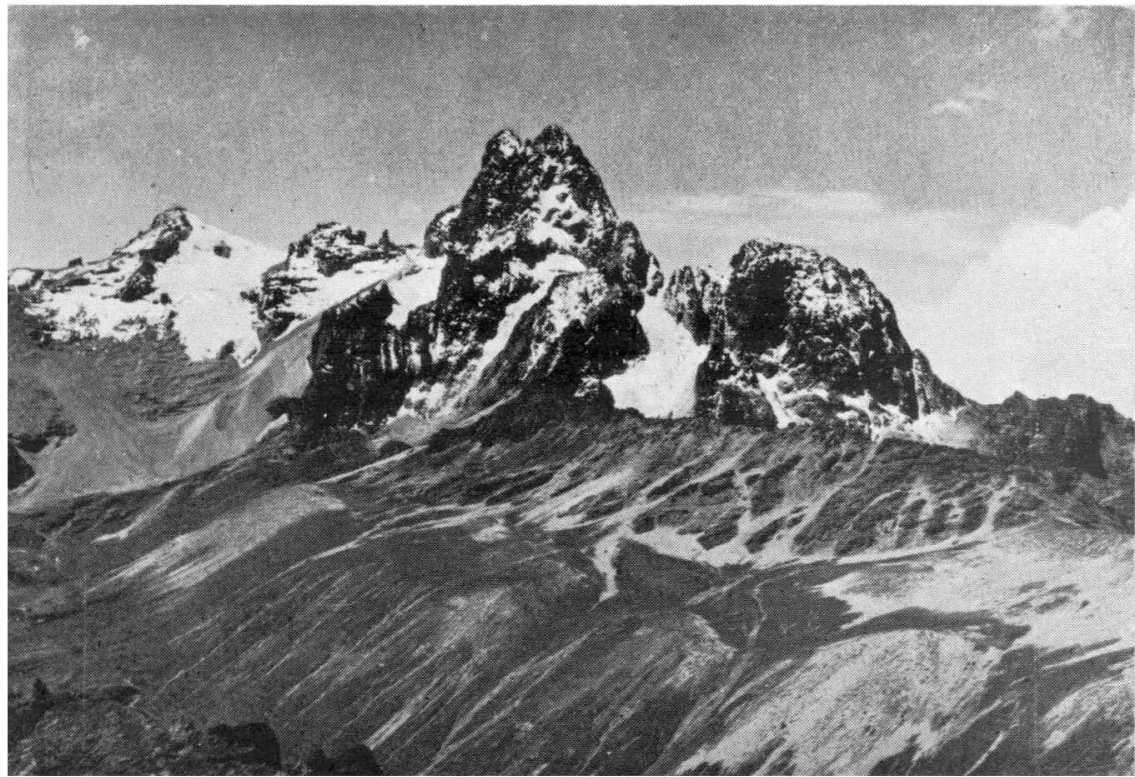

Aerial view of Mt. Kenya from the north-west. In the centre the twin peaks Nelion (I7,00o ft.) and Batian ( 17,040 ft.). Point Lenana on left

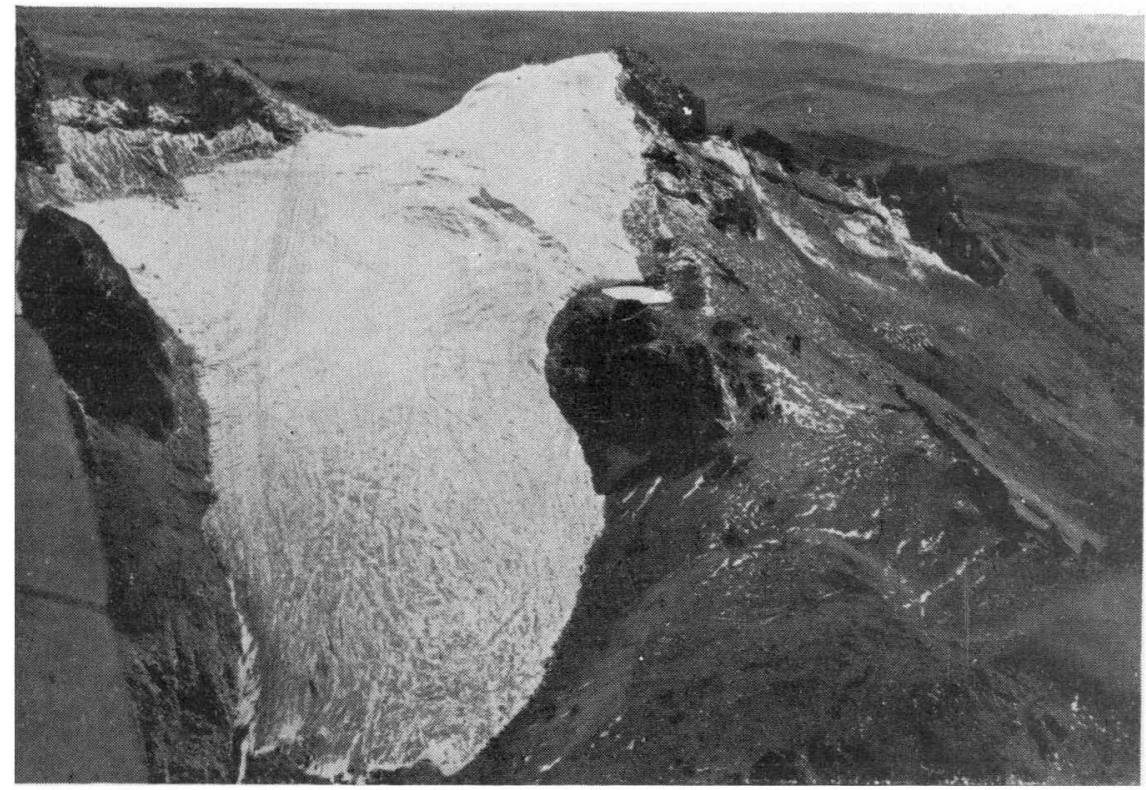

Aerial view of Lewis Glacier, Mt. Kenya. Point Lenana centre. Below is a corrie containing the "Skating Lake." The abraded surfaces of the rocks bordering the glacier provide evidence of the
former extension of the ice

Photographs by R.A.F. I945. Crown Copyright reserved 


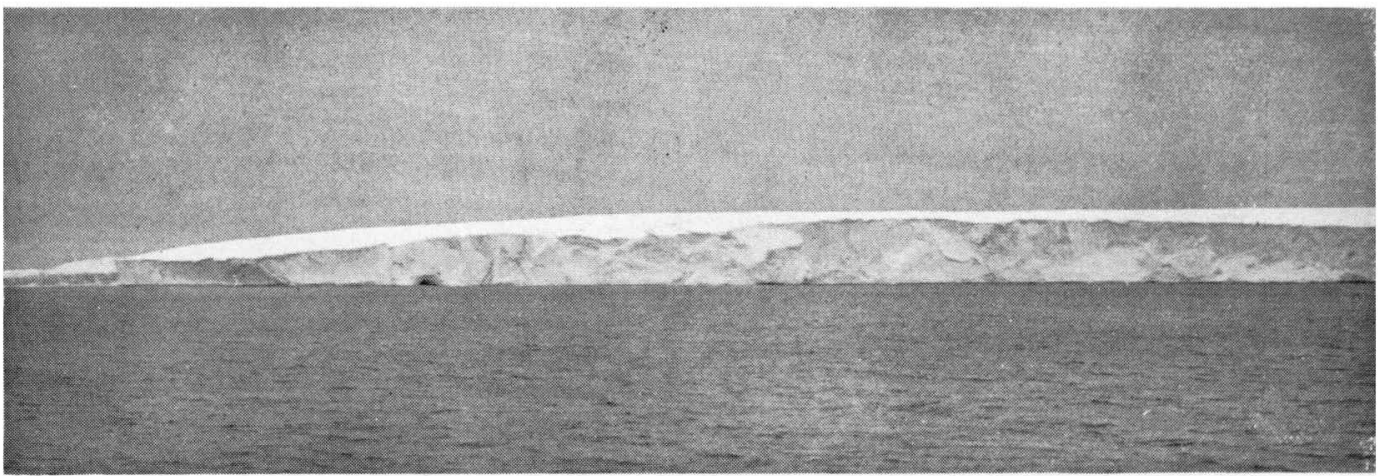

Dome-shaped iceberg off Ninnis Glacier tongue, King George $V$ Land

Photograph Dept. of Information, Canberra

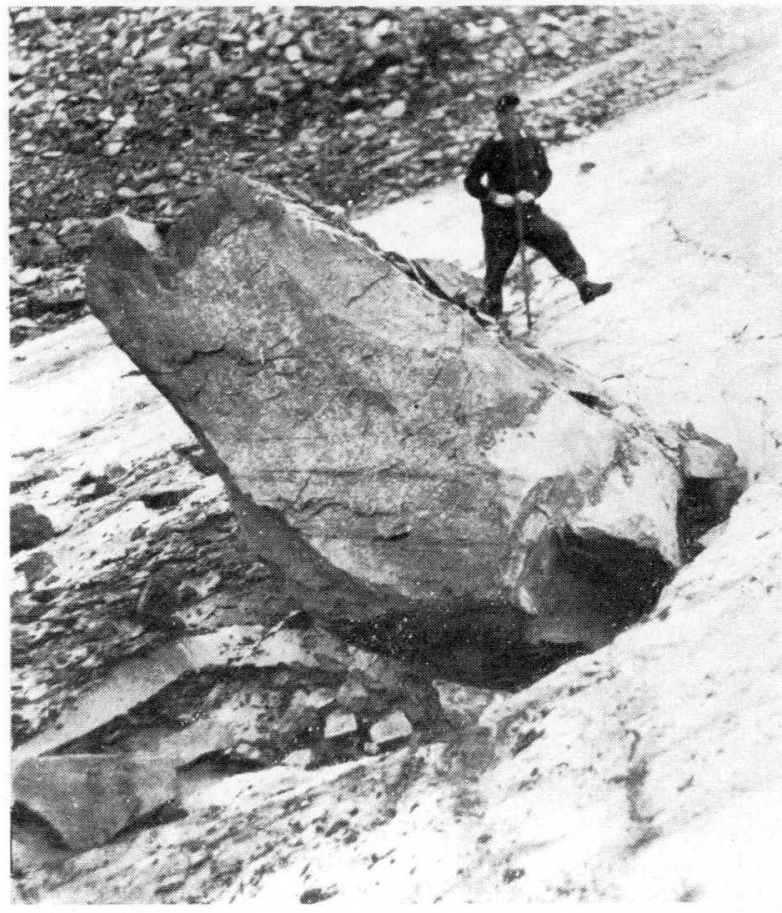

Fig. 7. A large boulder emerging along a thrust plane on the Skauthöe cirque glacier, Midt-Fotunheimen, Norway. (See text p. 236 )

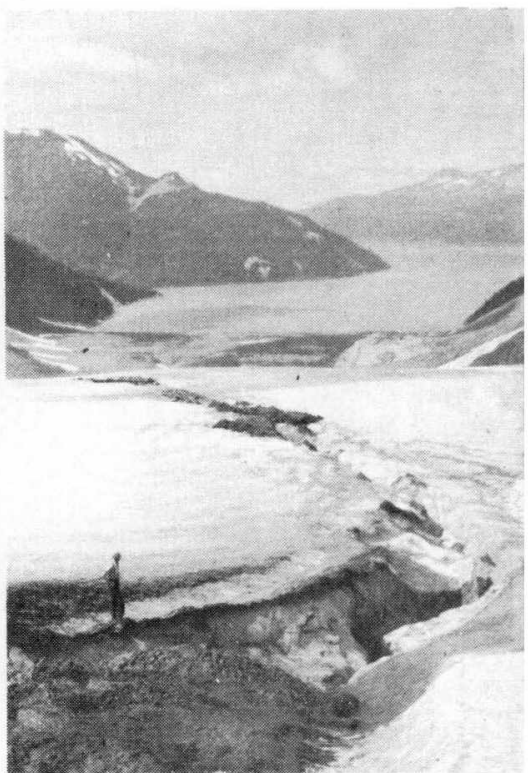

Fig. I. Trench and trail of debris (c.f. O T, p. 28 4, Fig. 2) left by the outburst of melt water on the Sentinel Glacier, Garibaldi Park, B.C., August 1946

Photograph by W. H. Mathews 